\title{
Fossil Wood from the Bituminous Sands of Alberta.
}

GINCE 1913 the Mines Branch of the Department of Mines of Canada has been carrying out, under the direction of $\mathrm{Mr}$. S. C. Ells, an extensive investigation of the bituminous sands (McMurray Tar Sands) of Northern Alberta. In a long communication to the Editor, dated Jan. 12, Mr. Ells directs attention to the presence of fossil wood in these sands. The discovery of fossil wood on the Ells River was first recorded by him in 1914, and later similar wood was obtained in shaft-sinking operations near MeMurray (Report 632, Mines Branch, Dept. of Mines, Canada, p. 55, 1925). Many of these specimens and others found later were sent to Prof. I. W. Bailey at Harvard University, who reported that one of the fossil woods belongs to some gymnosperm, not found growing in North America at the present day, which closely resembles in its wood-structure Sciadopitys, the parasol pine of Japan. Another he refers to the conifer Keteleeria, which is found in China and Formosa at the present day; while a third appears to belong to the type of wood called Xenoxylon, which has been found in Jurassic rocks. These three types, which may be referred to the three form-genera of fossil woods, Phyllocladoxylon, Protopiceoxylon, and Xenoxylon, from other records appear to have a atratigraphical range from the Jurassic onwards.

The fossil wood, which is found in the MeMurray Tar Sands in various-sized fragments, up to trunks at least $40 \mathrm{ft}$. in length, must have been transported, according to Mr. Ells, by water, and afterwards embedded in sand. The sands at a later date became saturated. with asphaltic base petroleum, which impregnated and preserved the cellular structure of the wood.

Other samples of these fossil woods were examined at the University of Alberta by Prof. F. J. Lewis, who, in a letter to the Editor, dated. Dec. 23, 1930, states that some of the fragments of wood belong to the form-genus Cupressinoxylon, a type of wood found in the cypress and several other conifers, living and extinct. He also mentions that some of the wood. is " Cordaitean in character with centripetal xylem" Without fuller details and photographs, it is impossible to express more than a guess as to the significance of these discoveries and identifications. Wood of Cordaitean type with centripetal xylem is what one might have expected to find in Palæozoic rocks. On the other hand, Cupressinoxylon, Phyllocladoxylon, Protopiceoxylon, and Xenoxylon would suggest a Mesozoic age for the beds. This is consistent with the fact that the beds immediately below are found to contain a Jurassic flora. It is to be noted that all the woods apparently belong to coniferous trees and there are no Angiosperms represented in the collection. This negative evidence is in favour of a Jurassic or very early Cretaceous age, before the advent of the Angiosperms. According to Mr. Ells, the discovery in the beds of two shells, of a Campeloma and a Melanoid belonging to the genus Pachymelania on Hangingstone River gives an additional clue to the age, for Campeloma has hitherto not been found in beds older than the basal part of the Cretaceous in America.

These various pieces of evidence, though not of much weight taken separately, point, on the whole, to an early Cretaceous age (or perhaps late Jurassic age) for the bituminous sands in which the fossil woods are found. However, until these fossil woods have been identified specifically and compared carefully with similar woods of known geological age, they are of little value as stratigraphical indices. One looks forward to the appearance of an adequately illustrated memoir on these interesting finds. The specimen of "Cordaitean wood" may be of considerable botanical interest.

\section{Cancroid Crabs of America.}

M SS MARY J. RATHBUN has completed a third part of her series of handbooks on American crabs in a work entitled "The Cancroid Crabs of America of the Families Euryalidæ, Portunidæ, Atelecyclidæ, Cancridæ, and Xanthidæ "'Smithsonian Institution, United States National Museum, Bulletin $152,1930)$. This monograph is on the same lines as those previously published, namely, "The Grapsoid Crabs of America" and "The Spider Crabs of America", and is equally valuable and well got up. Not only does it enable one to identify the American crabs, but also it helps all carcinologists with its detailed and carefully prepared classification, synonymy, and tables of distribution.

The Smithsonian Museum has recently been much enriched by large collections of crabs from South America obtained by Dr. Waldo L. Schmitt during his two series of explorations under the auspices of the Walter Rathbone Bacon scholarship. These, together with several exchanges from various museums, make the South American collections very valuable. Further investigations at the Tortugas and neighbourhood for the Carnegie Institution by Dr. Schmitt and Mr. Clarence R. Shoemaker in co-operation with Dr. William H. Longley, in charge of the Laboratory, have contributed much that is of interest; and collections have been added from the University of Southern California and the California Academy of Sciences.

A specially valuable find was a specimen of the extremely rare little crab Metopocarcinus truncatus
Stimpson, of which the type is not extant, and this is the only one known to exist in any collection. It is recorded from Cape St. Lucas, Lower California, Mexico, and Valparaiso, Chile.

It is with some reluctance that we call the common green crab Carcinides instead of Carcinus, but this alteration and the substitution of Euryalidæ for Corystidæ, to quote only one of many changes, are sound from the point of view of the International Rules of Nomenclature, as is also the restriction of the genus Portunus to those forms with nine lateral teeth each side of the carapace. Mr. Richard Palmer in his paper, "A Revision of the Genus Portunus (A. Milne Edwards, Bell, etc.)", in the Journal of the Marine Biological Association, N.S., vol. 14, No. 4, 1927, discusses the subject with much faimess, and one cannot help hoping that the general opinion will be in favour of keeping our British forms with five teeth each side of the carapace in the genus Portunus.

Nothing at all is said of the larval forms of any of the crabs, although now a good deal is known which is helpful in classification. This is, of course, in keeping with the other volumes, but it is to be hoped that the time is not far distant when larval characters will be as important as any of those of the adult, and that the structure of larvæ and adults together will form the basis of all systematic work.

The volume consists of 593 pages, containing many excellent figures, besides 229 beautiful photographic plates.

No. 3199, VoL. 127] 